\title{
Bacterial Meningitis Following Spinal Anesthesia for Caesarean Section
}

\author{
Qin Jian Low ${ }^{1}$, Kuo Zhau Teo', Seng Wee Cheo ${ }^{2}$ \\ ${ }^{1}$ Department of Internal Medicine, Hospital Sultanah Nora Ismail, Batu Pahat, Malaysia \\ ${ }^{2}$ Department of Internal Medicine, Hospital Lahad Datu, Lahad Datu, Malaysia \\ Email: peterlow4964@gmail.com
}

How to cite this paper: Low, Q.J., Teo, K.Z. and Cheo, S.W. (2018) Bacterial Meningitis Following Spinal Anesthesia for Caesarean Section. Journal of Biosciences and Medicines, 6, 1-4.

https://doi.org/10.4236/jbm.2018.610001

Received: August 26, 2018

Accepted: October 5, 2018

Published: October 8, 2018

Copyright ( 92018 by authors and Scientific Research Publishing Inc. This work is licensed under the Creative Commons Attribution International License (CC BY 4.0).

http://creativecommons.org/licenses/by/4.0/

cc) (i) Open Access

\begin{abstract}
Bacterial meningitis has a potentially devastating outcome if there is any delay in diagnosis and treatment. There are multiple routes at which bacteria could migrate into the subarachnoid space. Lumbar puncture bypasses the natural defense barrier of central nervous system and therefore carries a risk of transmitting infection to the meninges. We report a case of post spinal bacterial meningitis in a post partum lady who underwent spinal anaesthesia for emergency lower segment caesarean section. She developed signs and symptoms of meningitis twenty-eight hours post procedure. Her cerebrospinal fluid (CSF) analysis was suggestive of bacterial meningitis and she made a full recovery.
\end{abstract}

\section{Keywords}

Bacterial Meningitis, Spinal Anesthesia, Caesarean Section

\section{Introduction}

Meningitis after lumbar puncture and spinal anaesthesia is extremely rare with potentially serious complications if left untreated [1]. It can occur in various settings including spinal anesthesia, diagnostic lumbar puncture, epidural anesthesia or any procedures to the spinal canal. There are theoretically two routes at which bacteria can reach the cerebrospinal fluid i.e. failure of aseptic technique which exogenously introduces bacteria into the cerebrospinal fluid and migration of bacteria from blood stream into subarachnoid space via microscopic bleeding caused by the needle [2]. There is another entity called aseptic meningitis at which the meningitis is caused by hypersensitivity reaction or direct irritation of the meninges by medication administrated into the subarachnoid space [3]. Both entities of bacterial or aseptic meningitis may be hard to be differentiated as 
antibiotic is usually given prior to procedure. Another uncommon cause meningitis post-surgery is drug induced meningitis. Drugs related are non-steroidal anti-inflammatory drugs (NSAIDs), antibiotics and $\mathrm{H} 2$ receptor blocker [4].

This paper's objective is to report a case of post spinal anesthesia bacterial meningitis with curative treatment through antibiotics therapy. We will discuss the strategies of diagnosis and management of bacterial meningitis post spinal anesthesia.

\section{Case Report}

A 33-year-old lady, para 1 was admitted at forty weeks of gestation for reduced fetal movement. Her past medical history and antenatal history was unremarkable. She was apyrexial and her urinalysis was normal. She was counselled and agreed for induction of labour. However, after eight hours of induction of labour, her cardiotocography showed variable deceleration and an emergency lower segment caesarean section (LSCS) was performed. She was given intravenous cefuroxime $1.5 \mathrm{~g}$ as empirical antibiotic before her caesarean section. Skin disinfection was done using alcohol and chlorhexidine solutions. Subarachnoid block was done using intrathecal fentanyl $15 \mathrm{mcg}$, heavy bupivacaine $0.5 \%$ and morphine $0.1 \mathrm{mg}$. The LSCS was uneventful. Twenty-eight hours post LSCS, she developed fever of $39^{\circ} \mathrm{C}$, worsening headache and confusion. There were neck stiffness and Kernig's sign was positive. An urgent plain computed tomography brain done was normal. Diagnostic lumbar puncture showed an opening pressure of $25 \mathrm{~cm} \mathrm{H}_{2} 0$, turbid cerebrospinal fluid appearance with a white blood cell of 1470 cells $/ \mathrm{mm}^{3}$ with predominantly neutrophils. Cerebrospinal fluid glucose was $4.5 \mathrm{mmol} / \mathrm{L}$ with a CSF/Serum glucose ratio of 0.75 . Cerebrospinal fluid protein was raised at $2.4 \mathrm{~g} / \mathrm{L}$. No bacteria were seen on gram stain or culture. Her blood culture was negative. A diagnosis of post spinal bacterial meningitis was made. She was treated with two weeks of intravenous ceftriaxone $2 \mathrm{~g}$ twice a day. Her headache and fever resolved after forty-eight hours of intravenous antibiotics. She made an uneventful and complete recovery. She was discharged home with no neurological deficits. She remains asymptomatic with no evidence of neurological symptoms at her one-year follow-up.

\section{Laboratory Results}

\begin{tabular}{cccc}
\hline Parameters & Results & Units & Normal range \\
\hline White Cell Count & 20.57 & $10^{9} / \mathrm{L}$ & $4.0-10.0$ \\
Hemoglobin & 130 & $\mathrm{~g} / \mathrm{L}$ & $130-180$ \\
Platelet & 351 & $10^{9} / \mathrm{L}$ & $150-400$ \\
Alanine Transaminase & 31 & $\mathrm{U} / \mathrm{L}$ & Less than 40 \\
Urea & 3.9 & $\mathrm{mmol} / \mathrm{L}$ & $2.8-7.8$ \\
Sodium & 136 & $\mathrm{mmol} / \mathrm{L}$ & $135-148$ \\
Potassium & 3.6 & $\mathrm{mmol} / \mathrm{L}$ & $3.5-5.1$ \\
\hline
\end{tabular}




\begin{tabular}{cccc} 
Continued & & & \\
\hline Chloride & 85 & $\mathrm{mmol} / \mathrm{L}$ & $93-108$ \\
Creatinine & 60 & $\mathrm{mmol} / \mathrm{L}$ & $61-124$ \\
C-Reactive Protein & 120 & $\mathrm{mg} / \mathrm{L}$ & Less than 10.0 \\
Blood Cultures & Negative & & \\
CSF WBC & 1470 & $\mathrm{cells} / \mathrm{mm}^{3}$ & \\
CSF Glucose & 4.5 & $\mathrm{mmol} / \mathrm{L}$ & \\
CSF Protein & 2.4 & $\mathrm{~g} / \mathrm{L}$ & \\
CSF Culture & Negative & & \\
CSF Mycobacterium TB, & & & \\
Herpes Simplex, Bacterial & Negative & \\
Antigen, Indian Ink. & & \\
CSF/Serum Glucose Ratio & $4.5 / 6=0.75$ &
\end{tabular}

\section{Discussions}

Bacterial meningitis is an acute purulent infection of the subarachnoid space [5]. Possible etiology of post spinal meningitis includes break in the sterile technique with direct inoculation of bacteria, hematogenous spread with microscopic bleeding during spinal anesthesia in a septicemic patient and a less likely primary contamination of anesthetic drugs and equipment [6]. Every case requires thorough consideration to all etiological factors including equipment, drug and technique. Modern packaging and sterile techniques has almost eliminated these issues.

Early suspicion of meningitis post spinal anesthesia is vital in managing such patient. Meningitis should be a differential diagnosis in a patient with post spinal headache, fever, seizures and neurological deficits [7]. Blood culture and lumbar puncture should be planned early, and treatment should not be delayed while waiting for results. Brain computed tomography is warranted prior to lumbar puncture for patients who are immunocompromised, presented with new-onset seizure, showing signs and symptoms of raised intracranial pressure and focal neurological deficit [8]. Empirical intravenous antibiotic should be initiated and antibiotic therapy should be adjusted based on culture and sensitivities report [9]. Purulent cerebrospinal fluid but no growth on culture like in the case described may be because of prior administration of antibiotics or other causes like viral or aseptic meningitis [10].

We suspected bacterial meningitis in this case based on the clinical presentation and positive cerebrospinal fluid cell count. The cerebrospinal fluid culture and gram stain were negative possibly due to a course of empirical antibiotics before her caesarean section. Her clinical condition improved and she was discharged after completing her antibiotics. This is an isolated case in our center and there was no clustering of similar cases with a single anesthesiologist, single operation theatre and all cases are done with maximum sterile barrier precaution according to standard practice. 


\section{Conclusion}

Spinal anesthesia complicated by meningitis is rare. It is vital that physicians remain vigilant to detect meningitis when patient presents with headaches, pyrexia and signs of meningism in the post-operative period. Mortality is high but can be prevented with early diagnosis and appropriate treatment.

\section{Consent}

Written informed consent was obtained from the patient to publish the case.

\section{Conflicts of Interest}

The authors declare that they have no competing interests.

\section{References}

[1] Burke, D. and Wildsmith, J.A. (1997) Meningitis after Spinal Anaesthesia. British Journal of Anaesthesia, 78, 635-636. https://doi.org/10.1093/bja/78.6.635

[2] Tunkel, A.R., Hartman, B.J., et al. (2004) Practice Guidelines for the Management of Bacterial Meningitis. Clinical Infectious Diseases, 39, 1267-1284. https://doi.org/10.1086/425368

[3] Centers for Disease Control and Prevention (2010) Bacterial Meningitis after Intrapartum Spinal Anesthesia, New York and Ohio, 2008-2009. Morbidity and Mortality Weekly Report, 59, 65-69.

[4] Casico, M. (1996) George Health Meningitis Following a Combined Spinal-Epidural Technique in a Laboring Term Parturient. Canadian Journal of Anesthesia, 43, 399-402. https://doi.org/10.1007/BF03011721

[5] Lee, J.J. and Parry, H. (1991) Bacterial Meningitis Following Spinal Anaesthesia for Caesarean Section. British Journal of Anaesthesia, 66, 383-386. https://doi.org/10.1093/bja/66.3.383

[6] Harding, S.A., Collis, R.E. and Morgan, B.M. (1994) Meningitis after Combined Spinal-Extradural Anaesthesia in Obstetrics. British Journal of Anaesthesia, 73, 545-547. https://doi.org/10.1093/bja/73.4.545

[7] Goldman, W.W. and Sandford, J.P. (1960) An Epidemic of Chemical Meningitis. American Journal of Medicine, 29, 94-101. https://doi.org/10.1016/0002-9343(60)90010-3

[8] Bert, A.A. and Laasberg, H.L. (1985) Aseptic Meningitis Following Spinal Anesthesia: A Complication of the Past? Anesthesiology, 62, 674-677. https://doi.org/10.1097/00000542-198505000-00031

[9] Austin, D.A. and Sokolowski, J.W. (1968) Postlumbar Puncture Chemical Meningitis. New York State Journal of Medicine, 68, 2444-2446.

[10] Gibbons, R.B. (1969) Chemical Meningitis Following Spinal Anesthesia. JAMA, 210, 900-902. https://doi.org/10.1001/jama.1969.03160310088022 